\title{
A PRESUMPTIVE PHEROMONE-EMITTING STRUCTURE IN WOLF SPIDERS (ARANEAE, LYCOSIDAE)*
}

\author{
BY TORBJÖRN KRONESTEDT \\ Department of Entomology, \\ Swedish Museum of Natural History, \\ S-104 05 Stockholm, Sweden
}

The occurrence of pheromones in lycosid spiders has long been indicated on behavioural grounds. (For a review on chemical communication in spiders, see Tietjen and Rovner 1982.) There are bioassay evidences for (1) contact sex pheromones deposited on the substrate by females (Bristowe and Locket, 1926; Rovner, 1968; Hegdekar and Dondale, 1969; Richter et al., 1971; Dijkstra, 1976; Robert and Krafft, 1981), (2) contact sex pheromones associated with draglines laid by females (Kaston, 1936; Engelhardt, 1964; Richter et al., 1971; Dondale and Hegdekar, 1973; Tietjen, 1977, 1979b; Tietjen and Rovner, 1980; Robert and Krafft, 1981), (3) contact sex pheromones associated with female integument (Kaston, 1936), and (4) airborne sex pheromones given off by females (Tietjen, 1979a). Candidates for contact pheromone perception are chemosensitive hairs occurring on legs and palps. The number of these hairs is considerably increased in adult males in comparison to immatures and adult females (Tietjen and Rovner, 1980, 1982), and in certain lycosid genera this increase is rather drastic (Kronestedt, 1979a). No site of production and release of pheromones in wolf spiders has so far been found (Tietjen and Rovner, 1982). The present note focuses on a type of structure which is presumably involved in the release of pheromones in this spider family.

Studies on courtship behaviour in various lycosid species have been undertaken for supplementing morphological data in taxonomic contexts as well as for finding connections between adult male secondary sex characters and species-specific behavioural elements. Among the species studied, the adult male of Alopecosa cuneata (Clerck) has a unique character in its first tibiae being tumid

*Manuscript received by the editor January 8, 1986. 
(Fig. 1), the significance of which was unknown until the complete courtship sequence was observed (Kronestedt, 1979b, and ms. in prep.). Unlike what is common in lycosids, the female in this species plays a ritualistic active part in the premating display. The male is unable to mount the female before the following sequence has been passed through. The female will grasp one of the male's first tibiae with her chelicerae and pull him towards her, all the time holding her grip around his first tibia. This phase will last for approx. $10 \mathrm{~s}$. After being released, the male will immediately mount the female.

On each side of the swollen first tibiae there is an oblique depression which may aid the female in maintaining her grip. Moreover, these tibiae are black and strongly sclerotized (except for the depressions). Their unique shape is evidently essential in the premating display of $A$. cuneata, and thus also a strong isolating mechanism when connected to behaviour. What releases the grasping behaviour of the female? No definite answer can be given until further extensive experiments have been made. However, in trying to find whether there is any chemical cue involved, the male tibia was examined using SEM.

The cuticle of the first tibia in male $A$. cuneata is equipped with numerous pores (Fig. 2a), a condition hitherto unknown among lycosids. These pores could well be the emitting site for some type of aphrodisiac. In the closely related species $A$. pulverulenta (Clerck), with normal first tibiae in the adult male, less abundant and more scattered leg pores were observed (Fig. $2 b$ ). The latter condition was also found in adult females of the mentioned Alopecosa species and in both sexes of other lycosid species as well (Fig. 2c, d). Therefore, it is assumed that the situation in male $A$. cuneata is a special adaptation of a commonly occurring contact pheromone releasing system in lycosid spiders. If these presumptive pheromones are, at least in part, volatile, they are also candidates in olfactory communication, for which other receptors may operate (e. g. the tarsal organ: Dumpert, 1978).

Most investigators have focused on the means by which males find and recognize females. However, it is of utmost importance for the female to identify the proper male, as males are often less discriminant. Chemical recognition of males by females in lycosids is little studied but probably of significance (Tietjen and Rovner, 

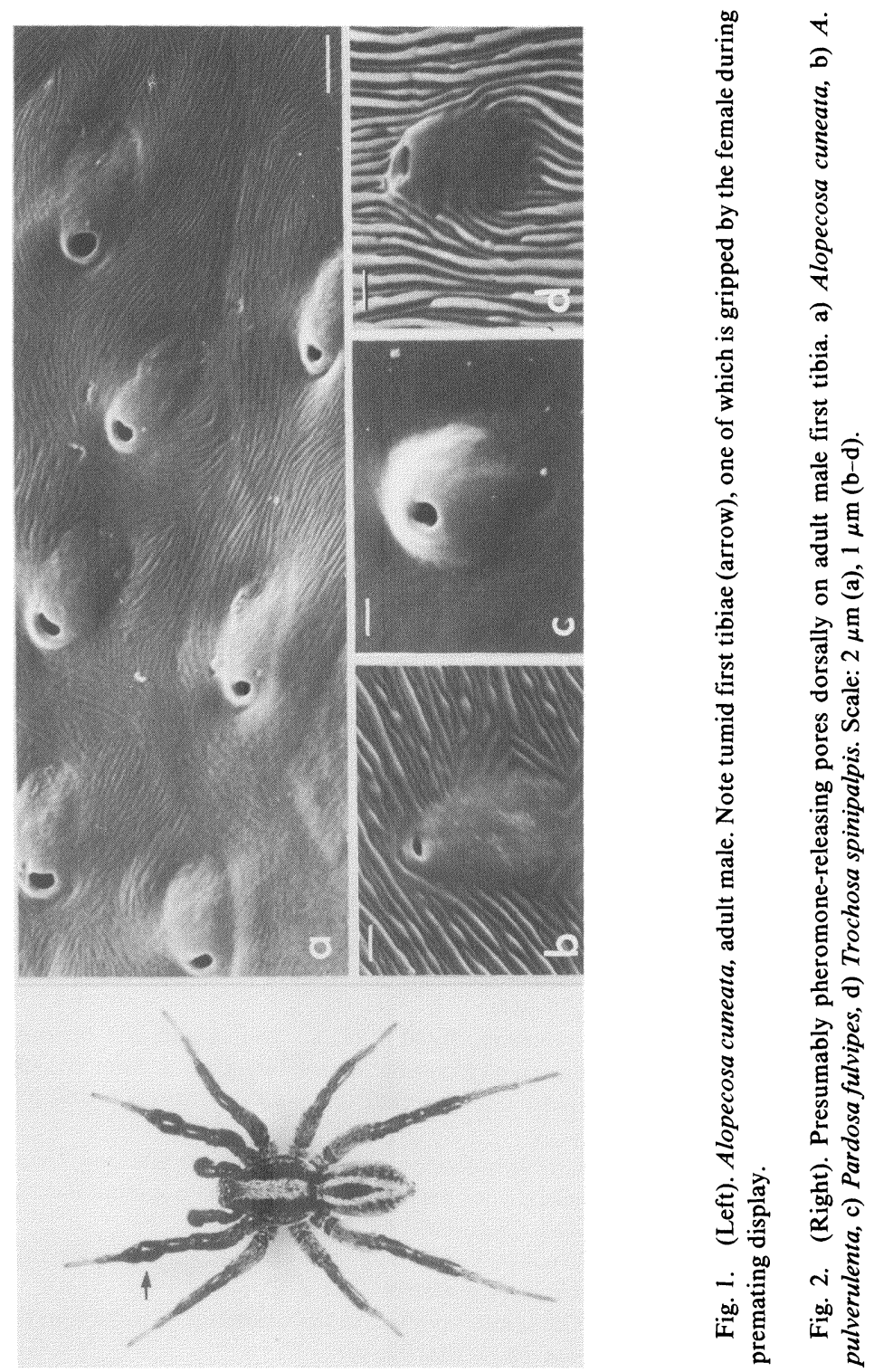
1982), as already assumed for nocturnal species of the genus Trochosa (Engelhardt, 1964).

Semiochemicals play an indispensible rôle in spider communication. Locating sites of pheromone production and perception is essential for understanding behaviours and morphological adaptations of sexual significance.

Specimens of Alopecosa cuneata (Clerck), A. pulverulenta (Clerck), Pardosa fulvipes (Collett), and Trochosa spinipalpis F.O.P.-Cambridge were all collected in pitfall traps with formalin in the vicinity of Stockholm, Sweden. The material was stored in ethanol, and parts used for SEM were dehydrated in an ethanol series, kept in xylene for one or two days, cleaned in ultrasonic cleaner, air-dried, mounted on SEM stubs, and sputter-coated with Pd-Au. Examination was carried out with a JEOL JSM-35 at $15 \mathrm{kV}$.

\section{SUMMARY}

The cuticle of lycosid spider legs is shown to be equipped with pores presumably involved in the release of sex pheromones. The pores occur in both sexes. The male of Alopecosa cuneata has an increased number of pores on its first tibiae, and the premating behaviour in this species speaks in favour of the male producing some aphrodisiac from the leg pores.

\section{Literature Cited}

Bristowe, W. S. AND Locket, G. H. 1926. The courtship of British lycosid spiders, and its probable significance. Proc. zool. Soc. Lond. 1926: 317-347.

Dijkstra, H. 1976. Searching behaviour and tactochemical orientation in males of the wolfspider Pardosa amentata (Cl.) (Araneae, Lycosidae). Proc. K. ned. Akad. Wet. (C) 79: 235-244.

Dondale, C. D. and Hegdekar, B. M. 1973. The contact sex pheromone of Pardosa lapidicina Emerton (Araneida: Lycosidae). Can. J. Zool. 51: 400-401.

DUMPERT, K. 1978. Spider odor receptor: Electrophysiological proof. Experientia 34: 754-755.

EngelHardT, W. 1964. Die mitteleuropäischen Arten der Gattung Trochosa C. L. Koch, 1848 (Araneae, Lycosidae). Morphologie, Chemotaxonomie, Biologie, Autökologie. Z. Morph. Ökol. Tiere 54: 219-392.

Hegdekar, B. M. and Dondale, C. D. 1969. A contact sex pheromone and some response parameters in lycosid spiders. Can. J. Zool. 47: 1-4.

KASTON, B. J. 1936. The senses involved in the courtship of some vagabond spiders. Entomologica am. (N. S.) 16: 97-167. 
Kronestedt, T. 1979a. Study on chemosensitive hairs in wolf spiders (Araneae, Lycosidae) by scanning electron microscopy. Zool. Scr. 8: 279-285.

KRONESTEDT, T. 1979b. Etologiska karaktärer vid taxonomiska studier av vargspindlar. Ent. Tidskr. 100: 194-199.

Richter, C. J. J., Stolting, H. C. J. AND Vlijm, L. 1971. Silk production in adult females of the wolf spider Pardosa amentata (Lycosidae, Araneae). J. Zool., Lond. 165: 285-290.

Robert, T. and KrafFt, B. 1981. Contribution à l'étude des méchanismes de la communication tacto-chimique intervenant dans le rapprochement des sexes chez Pardosa hortensis Thorell (Araneae, Lycosidae). Atti Soc. tosc. Sci. nat. Memorie (B) 88 (Suppl.): 143-153.

RovNer, J. S. 1968. An analysis of display in the lycosid spider Lycosa rabida Walckenaer. Anim. Behav. 16: 358-369.

Tietjen, W. J. 1977. Dragline-following by male lycosid spiders. Psyche 84: $165-178$.

Tietjen, W. J. 1979a. Tests for olfactory communication in four species of wolf spiders (Araneae, Lycosidae). J. Arachnol. 6: 197-206.

Tietjen, W. J. 1979b. Is the sex pheromone of Lycosa rabida (Araneae: Lycosidae) deposited on a substratum? J. Arachnol. 6: 207-212.

TietJen, W. J. AND Rovner, J. S. 1980. Trail-following behaviour in two species of wolf spiders: Sensory and etho-ecological concomitants. Anim. Behav. 28: 735-741.

TietJen, W. J. And Rovner, J. S. 1982. Chemical communication in lycosids and other spiders. In Spider communication. Mechanisms and ecological significance (P. N. Witt and J. S. Rovner, eds.): 249-279. Princeton Univ. Press, Princeton, N.J. 

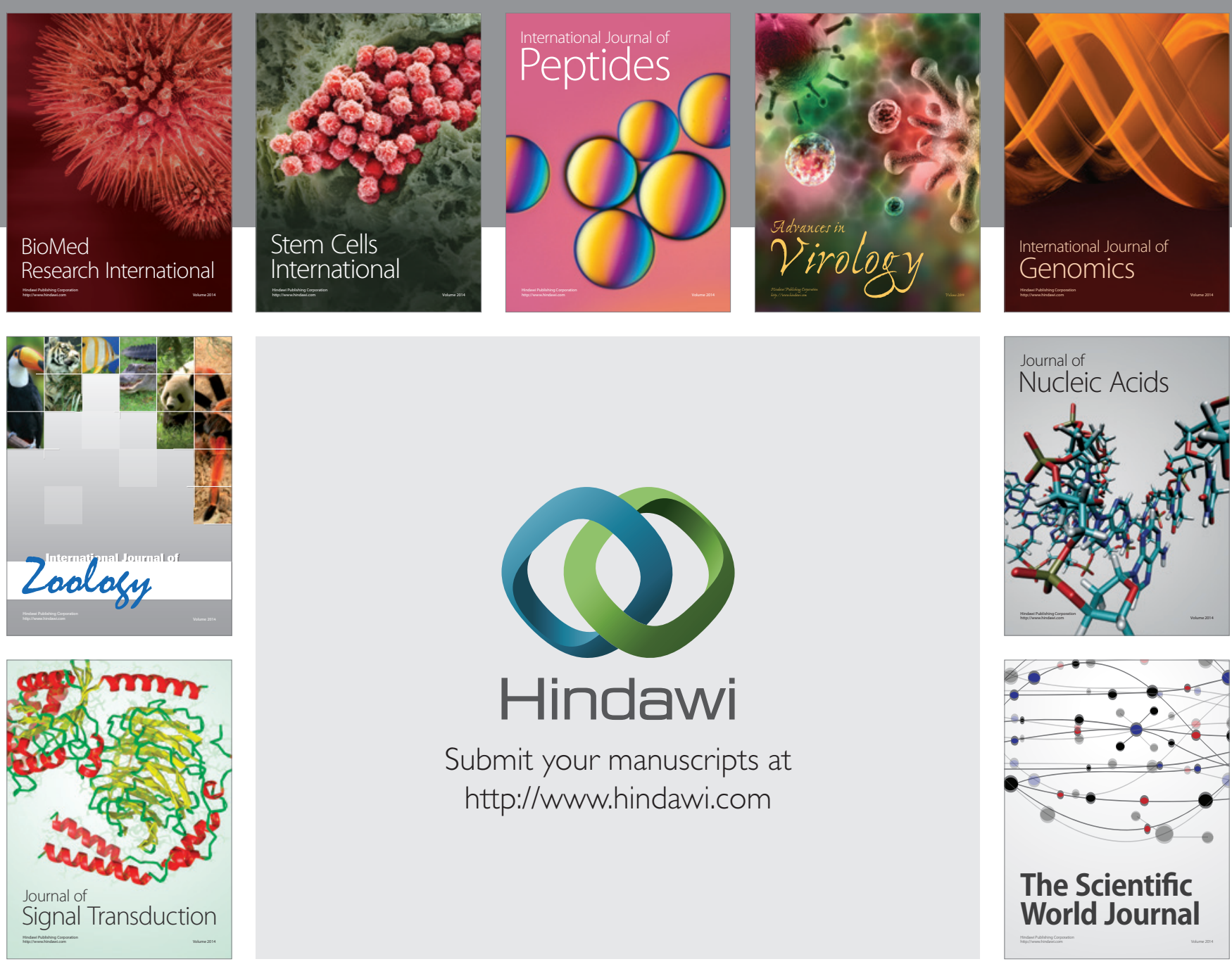

Submit your manuscripts at

http://www.hindawi.com
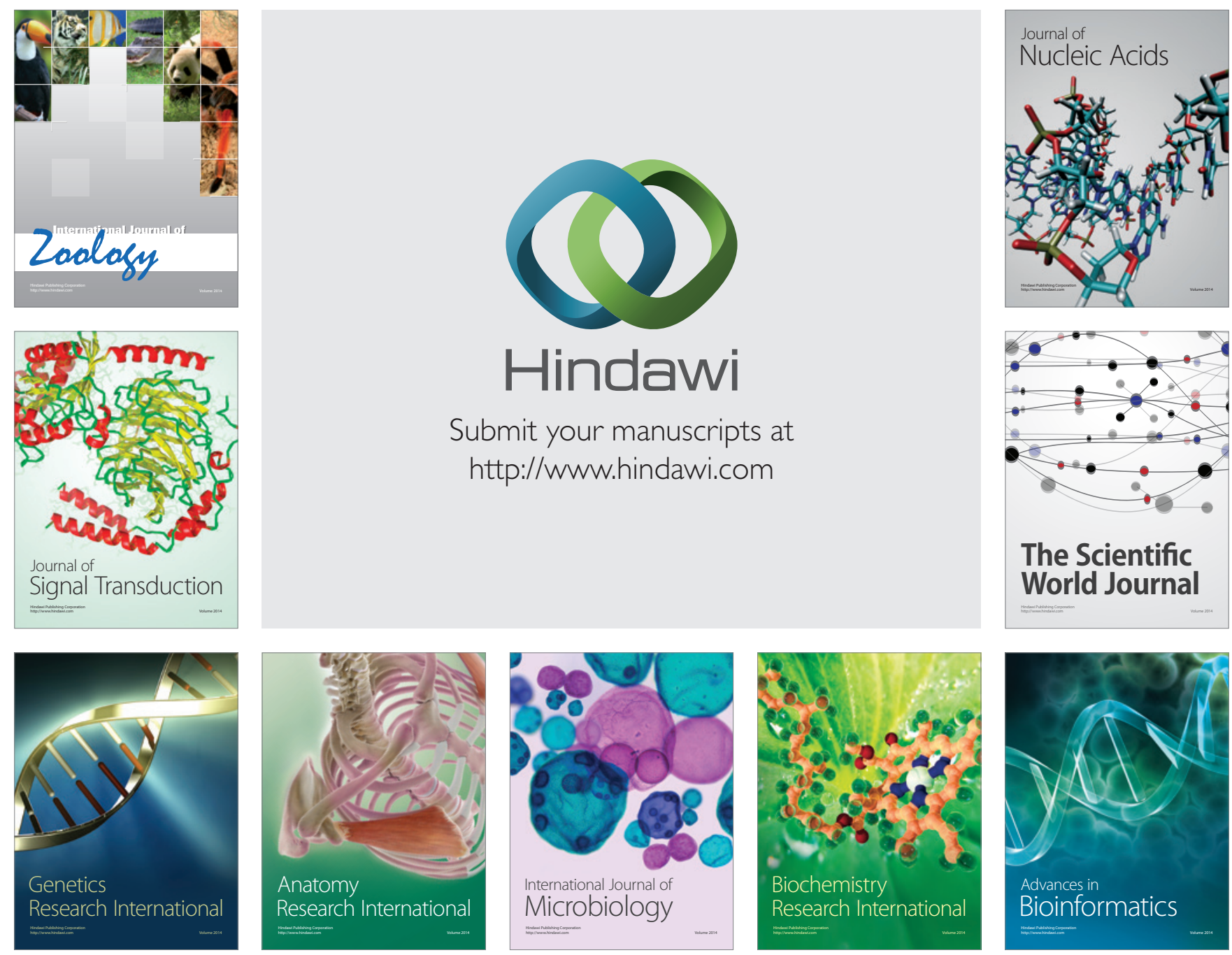

The Scientific World Journal
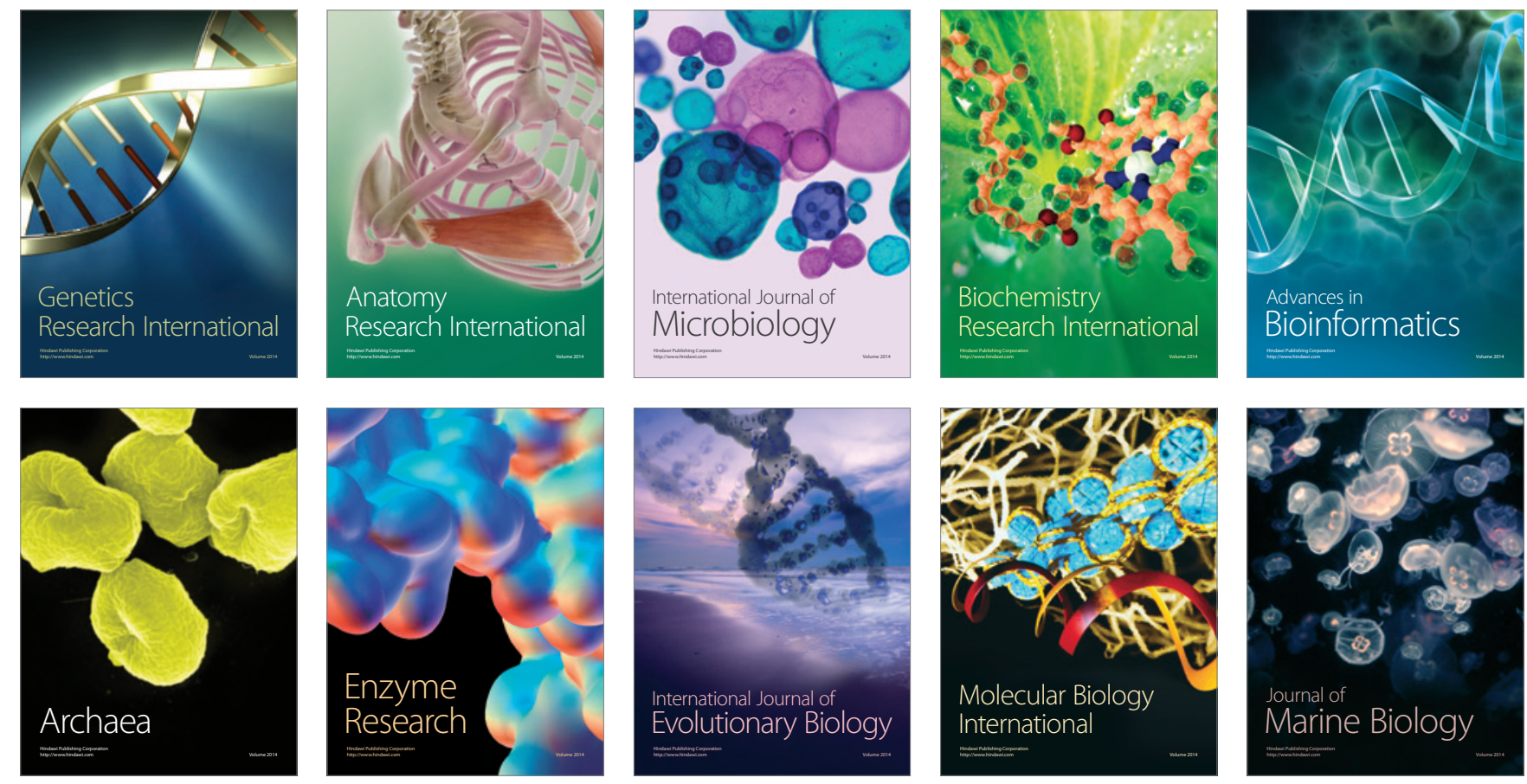